\title{
Sabbath controversy in Matthew
}

\author{
Author: \\ Francois P. Viljoen ${ }^{1}$ \\ Affiliation: \\ ${ }^{1}$ Faculty of Theology, \\ North-West University, \\ Potchefstroom Campus, \\ South Africa \\ Correspondence to: \\ Francois Viljoen \\ Email: \\ Viljoen.Francois@nwu.ac.za \\ Postal address: \\ Private Bag X6001, \\ Potchefstroom 2520, \\ South Africa \\ Dates: \\ Received: 19 July 2010 \\ Accepted: 16 Mar. 2011 \\ Published: 03 June 2011 \\ How to cite this article: \\ Viljoen, F.P., 2011, 'Sabbath \\ controversy in Matthew', \\ Verbum et Ecclesia 32(1), Art. \\ \#418, 8 pages. doi:10.4102/ \\ ve.v32i1.418
}

Jesus' attitude towards the Sabbath plays a crucial part in Matthew's argument. Some scholars argue that Jesus provocatively broke the Sabbath law; however, an attentive reading of the Sabbath controversies revealed a different reality. Matthew strategically places the Sabbath stories after he has firmly stated Jesus' teaching on the continuing validity of the law and the requirement of greater righteousness. The law and the prophets are fulfilled in the Person of Jesus, who demonstrated a fresh approach to Sabbath observance. God's intention with the Sabbath must also be recognised. Matthew argues not if the Sabbath should be observed, but how it should be done to experience true rest according to the will of God.

\section{Introduction}

Matthew's audience was surrounded and confronted by legalistic trends represented by the Pharisees of the Gospel. Jesus' relation to the law would have been a lively issue. In this situation, Matthew presents a foundational statement of Jesus with regard to the law (Mt 5:17-20). As the Sabbath played a key role in the Judaism in the time of Jesus and of the Matthean community, Jesus' attitude towards the Sabbath was a crucial part of the argument.

The Sabbath issue is explicitly expressed in two consecutive passages, Matthew 12:1-8 (paralleled in Mk 2:23-28 and Lk 6:1-5) and Matthew 12:9-14 (paralleled in Mk 3:1-6 and Lk 6:6-11). The two consecutive passages in Matthew 12 describe two separate events, but are jointly presented. All three Synoptic Gospels link them together, thus demonstrating the interconnectedness of the issues; however, Matthew places the Sabbath stories later in his gospel, after firmly stating Jesus' view on the law in the Sermon on the Mount.

In this article, I intend to indicate how Matthew applies the principles of Jesus' teaching on the law on the issue of the Sabbath. I do this by indicating the foundational role of Jesus' interpretation of the law (Mt 5:17-20), followed by the influence of views of the Sabbath in the times of Jesus. This leads up to the discussion of the Sabbath controversies (Mt 12:1-8 and 12:9-14). I read them in context of their co-texts, the preceding invitation by Jesus for rest (Mt 11:25-30) and the following confirmation that Jesus is God's chosen Son (Mt 12:15-21).

\section{The foundational statement (Mt 5:17-20)}

Jesus' relation to the Torah forms a central motive in Matthew's Gospel. Jesus' relation to the Torah is taken up in the Sermon on the Mount, specifically in Matthew 5:17-48 (Viljoen 2006:136). Jesus is seen as the last and greatest expositor of the law. Davies (1963:102) writes: 'Matthew has draped his Lord in the mantle of a teacher of righteousness'. All Matthew's statements about the law do not cohere easily. How should one understand the foundational statement on the continuing validity of the law in Matthew 5:17-20 in relation to inter alia the Sabbath controversies? A cursory reading of the Sabbath material could lead to the assumption that the Matthean Jesus is there presented as abrogating the law. Furthermore, one needs to attentively listen to Matthew's own argument. Scholars often interpret Matthew in the light of what he would have said if he were Paul.

Reading Matthew from this perspective, it becomes clear that he proposes that the love command and the call for mercy demonstrate the true requirement of the law. The law is the source of love and mercy. True holiness is always characterised by love and mercy. The love command (Dt 6:5 and Lv 19:18) encompasses the intention of the law and the prophets (Mt 22:34-40). The law and the prophets hang [kremat ai] on these two commands, because they determine how the other commands should be understood and applied. 'In Matthew's mind the love command is the prism through which the others are to be understood' (Snodgrass 1996:108). The verdict at end judgement is based on whether one practiced love. Parallel to the emphasis on love, is Matthew's emphasis on mercy, not as something different, but as another way of expressing the same 
idea. Matthew's double use of Hosea 6:6 ('I desire mercy, not sacrifice') signifies the intention of the law (Mt 9:13; 12:7). Acts of righteousness and mercy seem to be equated in Matthew 6:1-2. The mercy of God requires that people show mercy to each other. In Matthew, Jesus interprets the holiness code in terms of the mercy code. Everything is to be understood in the light of the requirements of love and mercy. To the question 'What is the law?' the answer is: 'The love command and the demand for mercy.' To the question, 'When is the law not law?' the answer is: 'When it is only law and not in keeping with the tenor of all the law and the prophets' (Snodgrass 1996:111).

It is also clear that Matthew proposes a prophetic reading and understanding of the law. Matthew presents his discussion on the law in relation to the prophets. Four of the eight occurrences of of nomo [the law] are in the expression ofnomo kai;0iJpr of ht ai [the law and the prophets] (Mt 5:17; $7: 12 ; 11: 13$ in reverse order and 22:40). Two more are in the contexts where the law is being discussed in the context of the prophets (Mt 5:18 and 22:36). Another is in context where the prophetic source Hosea 6:6 is quoted to validate Jesus' comments (Mt 12:5) and the last is an allusion to Micah 6:8 (Mt 23:23). Also, when the eating with unwashed hands becomes a dispute (Mt 15:1f.), a word from the prophets (Is 29:13) provides commentary on the hypocrisy. Even the regulations about the temple activities is determined by words from the prophets (Is 56:7 and Jr 7:11) in Matthew 21:13. The Pharisaic application of the law is not in line with the prophetic view and therefore, it is wrong (Mt 23:28). The law cannot be understood without the prophets. Jesus himself is presented as a prophet who gives the authoritative interpretation of the law.

Jesus declares: 'Do not think that I have come to abolish the law and the Prophets ... but to fulfil them' (Mt 5:17). The operative word is plhrws̀ i [fulfil]. Jesus did not come to set aside or nullify the Scriptures, but to affirm them and bring them to actuality in people's lives. The fulfilment of the Old Testament in Jesus is the basic orientation of Matthew's gospel (France 1998:196; Moule 1967/8:293-320; Viljoen 2007:302). This also forms the crux of Jesus' argument on the law (Moo 1984:24). 'Fulfil' in this context has the meaning of bringing to full intent and expression. Jesus' own coming then becomes the fulfilment of the law (Ladd 1993:123). Patte (1987:73) describes this fulfilment as the 'vocation' of Jesus. He did not oppose the Torah, but brought it to fruition (Carson 1982:77). The law finds it valid continuity in Jesus, the one towards whom it has pointed. With such an interpretation of Matthew 5:17 in mind, Banks (1974) remarks:

It is not so much Jesus' stance towards the law that he (Matthew) is concerned to depict: it is how the law stand with regard to him, as the one who brings it to fulfilment and to whom all attention must now be directed.

(Banks 1974:226)

Taking these considerations into account, the following interpretations of fulfilling can be considered. The relationship between Jesus' teaching and the law could be that he fills it up by expressing its full intended meaning; he completes the law by extending its demands and he brings the law to that which it pointed forward to. Thus, the law and the prophets have prophetic functions. The law can be viewed as an anticipation of Jesus' teaching and ministry. The statement 'until everything is accomplished' (Mt 5:18) does not as such point to the end of the world, but to the fulfilment of 'all' that God has planned. 'All' is accomplished not so much by the faithful observance of the law, but rather in that its preparatory function has been successfully achieved.

Matthew places the Sabbath controversies after Matthew 5:17-20 to clearly state the continuing value of the law. But Matthew refers to 'better righteousness' that is needed to enter the Kingdom of God. This righteousness is not a stricter adherence to the law, but adherence of a different kind. The debate is not about the recognition or obedience of the law, but about the understanding of the intention of God with the law (Hill 1978:117); therefore, Matthew argues not if the Sabbath should be observed, but how it should be done (cf. Carson 1982:98; Weiss 1990:25).

However, not all scholars agree. Rordorf specifically denies that Matthew 5:17-18 is an authentic saying of Jesus. He argues that Jesus' actions amount to deliberate provocative breaking of the law. His attitude is inter alia shown by the offensive incident of the disciples plucking grain and Jesus' reply that the Son of Man is Lord also of the Sabbath. "The Sabbath commandment was not merely pushed into the background by the healing activity of Jesus: it was simply annulled' (Rordorf 1968:70). According to Rordorf, Jesus' attitude must have been 'something monstrous' (1968:65) to the early church. Similarly, Brown (1966:210) remarked: 'that Jesus violated the rules of the scribes for the observance of the Sabbath is one of the most certain historical facts about his ministry'. Taking a closer look at the intention of the Sabbath and how Matthew presents Jesus' attitude towards the Sabbath, gives an answer to such allegations.

\section{Intention with the Sabbath}

The Sabbath in the Old Testament had a three dimensional scope (Bacchiocchi 1986:154).

The first dimension is found in the aetiology of the Sabbath. The Sabbath resonates God's rest [nuah] and blessings of the seventh day of creation (Gn 2:2-3; Ex 20:8-11). In the Old Testament, the notion of rest [menuhah] expressed aspirations for a peaceful life in a land of rest (Dt 12:9; 25:19; Is 14:3; 32:18) and God will find his 'resting place' amongst his people and especially in his sanctuary at Zion (1 Chr 23:25; 2 Chr 6:41; Ps $132: 8,13$, 14; Is 66:1).

The Messianic interpretation of the Sabbath provides the second dimension. The Sabbath served to symbolise the future peace and rest of the Messianic age. Mishna Tamid 7:4 views the time of redemption as: 'all Sabbath and rest in the life everlasting'. The divine blessing of the seventh day (Gn 2:3) in prophetic and rabbinic minds offered the basis of 
a Messianic age. The peace and harmony that once existed between Adam and the animals would be restored in the Messianic age when the wolf will live with the lamb, the leopard will lie down with the goat, the calf and the lion and the yearling together; and a little child will lead them ...' (Is 11:6). In those days, 'the earth will be full of the knowledge of the Lord as the waters cover the sea' (Is 11:9); therefore, one should behave on the Sabbath as if the peace and harmony of the Messianic age had already come. The availability and abundance in the Garden of Eden of 'trees that were pleasing for the eye and good for food' (Gn 2:9) inspired a prophetic vision of extraordinary abundance during the Messianic age. Amos declares:

The days are coming ... when the reaper will be overtaken by the ploughman and the planter by the one treading grapes. New wine will drip from the mountains and flow from all the hills.

(Am 9:13)

Similar descriptions are found in Isaiah 4:2, 7:22; 30:23-25; Baruch 29:4-6 and Enoch 10:17-19. Papias, one of the earliest Church Fathers (c. 60-130 AD), apply this vision almost verbally to an envisioned 1000 year reign (millennium) as the cosmic Sabbath, when Christ and the resurrected saints would enjoy peace and prosperity on the earth (as recorded by Irenaeus, Against Heresies 5:33, 3-4). A fitting description of the rabbinic expectation of the Sabbath is provided in an imaginative and dramatic Midrash:

Israel said before the Holy One, Blessed be He: 'Master of the World, if we observe the commandments, what will we have?' He said to them: 'the world-to-come.' They said to Him: 'Show us its likeness.' He showed them the Sabbath.

(cf. Bacchiocchi 1986:162)

Thirdly, the Sabbath commemorates God's deliverance. The creation story somehow is a deliverance story: deliverance from disorder to order, from chaos into cosmos. The repetition of the phrase 'it was good' (Gn 1:4, 10, 12, 18, 21, $24,31)$ portrays the picture of perfection and satisfaction. It also commemorates Israel's deliverance from Egypt (Dt 5:12-15), thus symbolising Messianic redemption. The release from the pressure of work and social inequalities is experienced on and through the Sabbath. This is pronounced in the prologue to both the Exodus and Deuteronomic versions of the Decalogue: 'I am the Lord your God, who brought you out of Egypt, out of the land of slavery' (Ex 20:2 and Dt 5:6). The Sabbath served not only to provide personal rest and liberation from social injustices, but also to epitomise and nourish the hope for future Messianic peace, harmony, prosperity, joy, rest and redemption form sin (Bacchiocchi 1986:176.) The ultimate purpose of the Sabbath has eschatological significance as it soteriologically signifies the eternal rest for the people of God as being pronounced in Hebrews 4.

God's Lordship of the Sabbath is frequently asserted as can be seen in the phrases 'my Sabbath' (Ex 31:12-17; Lv 19:3, 30 and 26:2). This day should be understood as a sign of the covenantal relationship between Yahweh and his people (Ez 20:12). In the observance of the Sabbath, the people should take delight in Yahweh (Is 58:13-14). The Edenic Sabbath offered the concept of 'Sabbath of delight': a day of joy, light, harmony and peace (Ps. 92). Prophets warn that a legalistic or hollow observance of the Sabbath, without observing its true covenantal character, is rejected by Yahweh (Is 1:13; Am 8:5). The Sabbath is not intended as a burden, but as an expression of God's mercy. That is why the Sabbath should be called a 'delight'. Yahweh detests formalistic Sabbath activities if it is accompanied with unmerciful behaviour (Is 1:15-17).

The Old Testament gives a different perspective to the Sabbath command as the later preoccupation with detailed casuistic regulations imposed by the Pharisees and rabbis. In Jewish literature, there were at least three stipulated lists of prohibited works on the Sabbath: Jubilees 50.6-13; Qumran, CD 10.14-11.8 and Mishnah Sabbath 7.2. These lists developed specific and meticulous regulations. The growing number of more specific regulations made the Sabbath inconvenient and burdensome. It directed the concern of the people from why they should keep the Sabbath to how they should keep it (Yang 1997:98). This obviously was the issue about the Sabbath in Matthew's narrative.

\section{Prologue to the Sabbath controversy stories: Rest for the weary (Mt 11:25-30)}

The Sabbath controversy pericopes are preceded by Jesus' invitation and promise of rest (Mt 11:25-30). The phrase 'at that time' (Mt 12:1) with which the Sabbath stories starts, ties this text to the previous pericope. The thematic correspondence can be recognised in several aspects.

Matthew 11:25 refers to the 'wise and the learned', which naturally refers to the opponents of Jesus, the Pharisees and scribes in particular. They were well versed in the Torah, but unreceptive of God's revelation in Jesus (Carter 2000:257). Obsessive in protecting their own interest and control, they became severe opponents of Jesus, throughout the Gospel and again with regard to the Sabbath.

In contrast to the 'wise and the learned', Jesus refers to 'little children' (Mt 11:25), who are privileged to receive the special revelation (Mt 11:27). The metaphor 'little children' indicates the receptiveness and humbleness of these people. Jesus probably includes his disciples in this category, the small community of disciples who have responded to Jesus' call. Matthew most likely also has the Christian community of his days in view (Luz 2001:181). The special revelation entails to the intimate relation between the Father and Jesus, which Jesus opponents did not realise. The repeated use of g inws kw [know] in the first 8 verses of Matthew 12 all refers back to 'these things' that are hidden from the wise, but revealed to children. To those to whom it is revealed it is also given to recognise the Father in his Son (Lybaek 1997:493).

Jesus invites people to 'come to me' (Mt 11:28), which echoes Wisdom's call (Pr 8:1-7; 9:4-5; Sr 24:19; 51:23-27). The 
ultimate wisdom is to be found with him (Davies \& Allison 2004:185). He extends a welcome to those who are 'weary and burdened', inter alia under the legalistic interpretation of the Torah by the Pharisees and the scribes. With Jesus' interpretation of the Torah it is different. The 'yoke' of Jesus (Mt 11:29-30) ${ }^{1}$ is easy in comparison with that of his opponents. In the Old Testament, 'yoke' is a symbol for foreign and harsh rule (e.g. Gn 27:40; 1 Ki 12:4-14). The release of the foreign yoke implies freedom and forgiveness (Isa. 9:3; 10:27). During the Second Temple period, the term 'yoke' was commonly used for the instruction of the Torah (e.g. 2 En 34:1-2; 2 Apoc Br 4:13; cf. Ac 15:10 and Gl 5:1) (cf. Deines, 2008:67). In Sirah 6:18-31 and 51:23-27 wisdom, law and yoke are linked together. The yoke of wisdom is the instruction of the law. Jesus' interpretation would be the easy yoke that he offers to the burdened. Matthew 11:27 mentions that 'all things have been committed to me', which affirms Jesus' authority as Son of God to interpret the Torah.

Jesus' gentleness (Mt 11:29) stands in contrast to the approach of the Pharisees. The 'rest (a japa us i ) for your souls' that is promised (Mt 11:29) anticipates the following Sabbath story. The Sabbath in the LXX was often translated with a jap a us i [rest] (Ex 23:23; Dt 5:14). This rest consists of peace of mind in the presence of God. Here, Jesus invites his audience to enjoy that kind of ajapaus i [rest] with him. 'Jesus is the true Sabbath' (Davies \& Allison 2004:187). The eschatological understanding of rest, especially in relation to the Sabbath, was well established (cf. $\mathrm{Hb}$ 4). Eschatological visions anticipated a return to the complete state of Gods' creation as before the Fall. The eschatological Sabbath rest that has been expected through Israel's history is now being fulfilled in Jesus. The ministry of Jesus as giver of rest is described in terms that announce the eschatological hope of redemption in the Hebrew Scriptures: 'The blind receive sight, the lame walk, those who have leprosy are cured, the deaf hear, the dead are raised and the good news is preached to the poor' (Mt 11:5). The association between Jesus, Sabbath rest and the eschatological hope adds force to the Christological argument of the Sabbath controversies. In his ministry of mercy and healing, the true meaning of the Sabbath has realised (Lybaek 1997:495).

Jesus repeats his invitation with a parallel imperative: 'take my yoke upon you ... and you will find rest for your souls ...' (Mt 11:29-30). Jesus invites people to be liberated from the 613 legalistic commands which the Pharisees required them to obey.

It is obvious that the controversy stories about the Sabbath should be read in context with this preceding pericope. The Sabbath needs to have a new form in the presence of the 'Lord of the Sabbath' (Mt 12:8). Jesus brings true rest to those being burdened by the legalistic understanding of the Sabbath. The prologue provides Christological affirmation of the Person of Jesus and provides an invitation to see, hear and understand true wisdom.

1.The words of Ben Sira show close resemblance to this logion: 'Put your neck unde her (Wisdom's) yoke' (Sr 51:26).

\section{The picking of corn on the Sabbath (Mt 12:1-8)}

With his opening words 'ej ekei w/t w/ka ir w' [in that time] (Mt 12:1), Matthew links the story of the picking of the corn with the preceding pericope. Matthew depicts the liberating yoke of Jesus in the Sabbath praxis. He compares the easy yoke of Jesus over and against the heavy burden of the Pharisees (Carson 1982:66). Jesus is confronted by the Pharisees. Throughout his gospel Matthew portrays the Pharisees as opponents of Jesus. They are critical of Jesus' behaviour and malicious in their intent. The observance and meaning of the Sabbath was one of several reasons of conflict between the Pharisees and Jesus.

Matthew puts Jesus at the forefront of the story 'Jesus went ...' (Mt 12:1). This is significant when read along with the closing of the story 'For the Son of Man is Lord of the Sabbath' (Mt 12:8). Matthew thus makes use of an inclusio. It is also remarkable that the Pharisees accused Jesus and not his disciples, who were actually picking the corn (Mt 12:2). Matthew intentionally focuses on Jesus' position. Only the Matthean version mentions that the disciples were hungry. This version is often regarded as a softening of the Markan text, as to make the actions of the disciples acceptable according to halakhic [Jewish religious law] regulations. Mishnah Sabbath 14.3 and 22.6 make provision that work in the Sabbath is acceptable to prevent the loss of human life; however, there surely was no threat of life in this case, which makes such halakhic [Jewish religious law] exception irrelevant (Deines 2008:67). On the other hand, Matthews omits the Markan more casual 'as they made their way' (Mk 2:23) and replaced it with the more formal 'they began to pick corn' (Mt 12:1), which sounds more like work. The Pharisees' accusations must have been based on their assumption that the disciples were engaged in the work of reaping. The rubbing of the grain between the hands and blowing to remove the husks could be understood as threshing and winnowing (Morris 1992:300). Reaping, threshing and winnowing were all listed under the 39 categories of work that were prohibited by Mishnah Sabbath, 73B. Matthew's argument rather lies in Jesus' response. Jesus responds to the accusation with four arguments.

In his first argument (Mt 12:3-4), Jesus refers to David and the showbread (1 Sm 21:1-6). This appeal of Jesus raises several questions. One could assume that Jesus argued that if a righteous man like David could break the law, the disciples could do so too; however, this is unlikely. Jesus never accepted that his disciples in fact broke the Sabbath law. The fundamental reason for Jesus' appeal to 1 Samuel 21:1-6 should rather be related to the stating of the authority of Jesus. As David the king had the authority to interpret the law, Jesus, the ultimate king and messiah has the authority to a higher degree (France 1971:47). It is important to recognise this implicit David-typology: 'Someone greater than David is here' to understand the explicit claim in the temple-typology in the following response (Yang 1997:176). 
Matthew follows with Jesus' second argument (Mt 12:5-6) in response to the Pharisees' accusation. The priests were permitted to desecrate the Sabbath by performing their duties in the temple. One only has to consider the work involved in dismembering and burning the Sabbath sacrifices (Nm 28:110) (Levine 1976:481). This response of Jesus seems to appeal to one of the well-known rabbinic exceptions. According to Tannaitic literature, the rabbis allowed the violation of the law for at least six occasions, namely circumcision, Passover, saving Scriptures or food from the fire, self defensive war, saving a life and temple service (Yang 1997:84); however, it is highly unlikely that Jesus would deal with rabbinic casuistry. The actual argument lies in verse 6, where Jesus proclaims his own authority: 'Someone greater than the temple is here'. Jesus explicitly makes use of temple-typology, linking on to his previous implicit David-typology. As the presence of God could be experienced in the temple, it can now be experienced in the company of Jesus. Jesus is greater than the temple. This was a very strong claim to make, as the temple was seen as the centre to Israel's religious and political tradition. The temple was much more than a religious building. It was the focus of national identity and the visible symbol that Israel was the chosen people of Yahweh. Jesus supersedes what was before as the role of the temple is transferred to and fulfilled in him (France 2008:109). The fulfilment of God's presence is a central motive in Matthew's Gospel (cf. Menken 2004:12). He begins the Gospel with 'Immanuel, God with us' (Mt 1:23) and concludes with 'I am with you always ...' (Mt 28:20). This motive is asserted with Jesus' words: 'For where two or three come together in my name, there I am with them' (Mt 18:20). If the temple has more authority as the Sabbath because it manifests the presence of God, then Jesus (who is the replacement and fulfilment of the role of the temple) has even more authority as the Sabbath (Mt 12:8). As the priests were guiltless whilst working in the temple on the Sabbath (as the temple had authority over se Sabbath), so much more are the disciples of Jesus as they are in his presence. The authority and presence of Jesus create new attitudes and new ways of observance of the Sabbath (McIver 1995:242).

Jesus' third response to the accusation (Mt 12:7) also appears only in Matthew. Jesus appeals to Hosea 6:6: 'I desire mercy, not sacrifice'. By its insertion into the Markan Vorlage, Matthew typifies the character of God who is the merciful rather than the demanding one. He wants loving-kindness, rather than blind sacrifice. In Matthew 'the compassionate attitude and merciful action which give concrete expression to one's faithful adherence to and love for God' (Hill 1978:110) rather than blind sacrifice is required. 'Es legitimiert die Freigabe des Sabbats für die Liebestat gegenüber dem Pharisäismus' (Hummel 1963:45). The character of the fulfiller of this will of God is being demonstrated in the Person of Jesus. Mercy [ejeo ] is the guiding principle of the ministry of Jesus (Lybaek 1997:493). Therefore, Jesus declares that mercy is more important than temple-sacrifice. Under the authority of Jesus, his disciples understood the ultimate intention of the Sabbath. In contrast to this mercy, the antagonistic and unmerciful character of the Pharisees starkly culminates.
In Matthew 12:7 Jesus, for the second time, quotes from Hosea 6:6. This is the only quotation to be repeated in the Gospel and clearly is of special importance for Matthew (Hill 1978:107). Matthew probably found the quotation particularly applicable for his community, who struggled because of the strenuous separation from their Jewish mother-religion and community. With this double occurrence, Matthew connects the material of Matthew 12:7 with Matthew 9:13. In both cases, Jesus is represented as in dispute with the Pharisees and passing judgment on their conduct. The quotation is introduced in similar ways: 'Go and learn what this means' (Mt 9:13) and 'If you had known what the words mean' (Mt 12:7). In both occasions, these words are directed to the antagonistic Pharisees. Furthermore, both passages are preceded and followed by Christological pronouncements (Lybaek 1997:496). In Matthew 9, Jesus' practical compassions is described as he forgives sins (Mt 9:6) and has fellowship with 'tax collectors and sinners', whom he calls to become disciples (Mt 9:1-13). Christologically interpreted, the quotation in both contexts illustrates the praxis of Matthew $5: 17$.

In the original context of the citation in Hosea, eveo [mercy] refers to the faithfulness and covenantal loyalty of God. Hosea repeatedly warns Israel against its disloyalty and calls God's people to repent. With his repeated use of this quotation, Matthew alluded to this Hosean context of an urge to repentance and covenantal loyalty to God. Matthew implied an urge for an on-going fellowship with God and a prophetic judgment against those who would not recognise the mercy of God in the ministry of Jesus. It is therefore clear that in quoting Hosea 6:6 there is more at stake as the mere defence of the disciples' behaviour.

Jesus' fourth argument forms the climax of this response: 'For the Son of Man is the Lord of the Sabbath' (Mt 12:8). Jesus declares his Lordship over the Sabbath outright. In the Old Testament, God's Lordship over the Sabbath is repeatedly expressed (e.g. Ex 16:23, 25; 20:10; 31:15; 35:2). This Lordship that was in the Old Testament repeatedly claimed by God is now claimed by Jesus as the Son of Man². He has come to fulfil the Sabbath and therefore has the right to claim Lordship. The law came under the authority of Jesus. The disciples' action was acceptable in terms of who Jesus was (McIver 1995:240).

\section{Healing of the man with the withered hand on the Sabbath (Mt 12:9-13)}

The story of the disciples picking corn is directly followed by the episode of Jesus' healing of the man with the withered hand. Matthew directly links these two events with 'going on from that place, he went into their synagogue' (Mt 12:9).

2.The background for Matthew's 'Son of Man' most probably should be seen in Danie 7:13-14. The majority of Matthew's uses of the term relates to the vindication and 7:13-14. The majority of Matthew's uses of the term relates to the vindication and
glory of the Son of Man with references to clouds, heaven, coming, glory, kingdom and judgment (France 1989:291). 
Significantly, Matthew sets the scene as in 'their synagogue'. In Matthew, the synagogue is a place of confrontation ${ }^{3}$. Matthew makes the antagonism of the Pharisees more explicit than in the other Synoptic Gospels (Mk 3:2 and Lk 6:7). Their unspoken thoughts (as in Mark and Luke) are converted into an explicit question: 'Is it lawful to heal on the Sabbath?' and test case 'Looking for a reason to accuse him' (Mt 12:10). The Pharisees' concern is not for the man as such, but for a reason to challenge Jesus. Although the Torah itself nowhere forbids healing on the Sabbath, halakhic [Jewish religious law] regulations $\mathrm{did}^{4}$. Tosephta Sabbath 16:22 reads: 'Contributions for the poor are not allotted on the Sabbath in the synagogue ... and one does not pray for the sick on the Sabbath'. The only exception for healing on the Sabbath was in the case of immediate danger of life (Mishnah Sabbath, 14.3; 22.6). A life threatening situation was the 'borderline' for the Pharisees that made it acceptable to transgress the Sabbath commandment. But this was not the case here. According to Pharisaic halakhic [Jewish religious law] stance, the healing of the man with the withered hand therefore was unlawful as his life was not in immediate danger (Deines 2008:67).

Jesus responds by asking whether it is permissible to rescue one's sheep $^{5}$ on the Sabbath (Mt 12:11). Jesus speaks of a man who has only one sheep. Matthew emphasises this by placing ef [in] after the noun. Jesus argues that if a poor peasant is dependent on his only sheep, he will obviously save it. The Pharisees had different views whether it would be allowed to pull one's (only) animal out of a pit on the Sabbath (Luz 2001:187). Later rabbis developed a subtle mediation solution: One may help the animal, but it must come out of the pit by itself. According to the Talmud, rabbi Judah said in Rab's name:

If an animal falls into a dyke, one brings pillows and bedding and places (them) under it, and if it ascends it ascends. An objection is raised: If an animal falls into a dyke, provisions are made for it where it lies so that it should not perish. Thus only provisions, but not pillows and bedding.

(Rab Sabbath 128b)

The editor's comment to this argumentation is noteworthy: '(The avoidance of) suffering of dumb animals is a Biblical (law), so the Biblical law comes and supersedes the (interdict) of the rabbis'. It is not clear whether the Pharisees in Matthew's story accepted this priority over the rabbinic Sabbath ruling.

As an a fortiori argument (or as the rabbis termed it qal wahomer), Jesus adds an emphatic statement: 'How much more valuable is a man than a sheep!' (Mt 12:12a). Jesus' argument is clear, that if it is permissible to relieve an animal of its suffering on the Sabbath, it surely should also be

3. Matthew uses the phrase 'their synagogues' five times (Mt 4:23; 9:35; 10:17; 12:9; 13:54) and 'your synagogue' once (Mt 23:34) to underline the distance between Jesus and the synagogue community. Several of these passages also emphasise hostility between the synagogue and Jesus' disciples. In Matthew 10:17, Jesus warn his disciples that they will be flogged in 'their' synagogues. In Matthew 13:54-58, 'their' synagogues reject Je sus. In Matthew 6.2 and 5 and 23:6, the behaviour of 'the 'hypocrites in the synages' is condemned and contrasted with that of ' $y 0 u$ ' in the Christian groups.

4.By the end of the 2nd century A.D., the oral Torah (Halakah) became just as authoritative as the written Torah (Carson 1982:76).

5.Luke 14:5 has a partial parallel referring to an ox. permissible to do the same for a human being. Thus, Jesus points out the inconsistency and inhumanity of their halakhic [Jewish religious law] system (Yang 1997:204). This argument of Jesus recalls his words previously reported: 'Is life not more important ...' (Mt 6:26) and 'you are worth more than many sparrows' (Mt 10:31). Those references also expressed God's compassionate care for his people, which reaffirms the argument.

Jesus concludes his argument with a climax that is not based on halakhic rulings: 'Is it lawful to do good (kal wi poi ein) on the Sabbath?' (Mt 12:12b). 'The Sabbath commandment is, for Matthew, the obligation "to do good"' (Hill 1978:116) and love becomes the commandment's centre (Luz 2001:188). The Pharisees were concerned about strict halakhic [Jewish religious law] rulings and their eagerness to accuse Jesus. Jesus, on the other hand, sees the need of the man with the withered hand and is concerned to recognise in this situation the original intention of God for the Sabbath. Jesus' remark is neither halakhic [Jewish religious law], nor a repetition of Old Testament commandments. Jesus proposes this general principle on his own authority as 'Lord of the Sabbath' (Mt 12:8) (Hagner 1993:334). This answer assumes messianic authority. Jesus' words link up with the principle stated by the quotation from Hosea 6:6, 'I desire mercy, not sacrifice' in the previous scene (Mt 12:8). Jesus' argument is clear: He was not abolishing the law, but fulfilling it by demonstrating the actual intention of the Sabbath. To do good on the Sabbath is totally permissible as it is in line with God's original will for the Sabbath. The Sabbath is instituted to express God's mercy for human beings. Doing good is not a an act of abolishing the law (Sabbath) or merely of keeping the Sabbath, but an act bringing the principle to fulfilment. The Pharisees must have experienced this argument rather provocative than persuasive.

Immediately after his pronouncement, Jesus applied his pronounced principle by healing the man's hand (Mt 12:13). Jesus healed the man by a word. Unlike the incident recalled in Matthew 9:6, Jesus did not command the man to carry his mat and unlike the incident in John 9:6, Jesus did not make clay. The healing and the manner in which he did it bring additional support to Jesus' authority as 'Lord of the Sabbath' (Mt 12:8). He is the promised one who brought God's reign to his people.

The healing evoked an antagonistic response from the Pharisees. Yang (1997:210) remarks: 'They could not stay in the synagogue any longer ... because of Jesus' overwhelming authority in the synagogue'. As Jesus came into the synagogue, the Pharisees had to leave. The lack of genuineness in their original question was exposed. Their authority in the synagogue and their image amongst the people were threatened by Jesus' authority. But the real tragedy for the Pharisees was not simply their failure to understand and accept Jesus' argument, but more fundamentally, their failure to receive Jesus himself as the Messiah who brought the kingdom and became the 'Lord of the Sabbath' (Hagner 1993:334). The Pharisees decided that Jesus had to be removed if their authority and influence were 
to remain intact. Whilst Jesus delivered the man from his burden and gave him wholeness of life, the Pharisees used this merciful action as an occasion to conspire to destroy his life. Ironically, the so-called guardians of the Sabbath arranged to remove the Lord of the Sabbath (Yang 1997:211).

\section{Epilogue to the Sabbath controversy stories: God's chosen one (Mt 12: 15-21)}

Jesus' Christological affirmation is developed in the fulfilment quotation following the Sabbath controversy. Matthew cites from the servant song in Isaiah 42:1-4. This citation forms Matthew's longest quotation. This quotation defends the position of Jesus in this highly polemical context.

The brief report on Jesus' withdrawal and healing ministry (Mt 12:15-16) functions as a bridge from the previous scene and an extended introduction formula to the quotation to follow. In this report, Jesus' mercifulness is sharply contrasted with the aggressive opposition of the Pharisees in the previous scene. The quotation has several thematic points of contact that links the quotation with the preceding Sabbath stories (Neyrey 1982:459). Jesus' announcement as being the Lord of the Sabbath and healing ministry comes as further witness that he is the promised one, the servant Messiah, who came to fulfil the Old Testament. Matthew uses Isaiah 42:1-4 as a Christological portrait of Jesus to illuminate the preceding events.

By quoting the servant song: 'Here is my servant (child) whom I have chosen, the one I love ...' in Matthew 12:1821, Matthew affirms that Isaiah's prophecy has reached its fulfilment. Jesus is God's chosen one. According to Isaiah 42:1-4, the servant (Jesus the Messiah for Matthew; cf. Mt 12:18-21) would bring mispat and Torah (cf. Nm 24:17; Dt 18:18-19; Is 52:7; 61:2-3; Dn 9:25). John describes a similar expectation with the Samaritan woman who expressed her faith that when the Christ comes, 'he will explain everything to us' (Jn 4:25). These expectations clarify Matthew's presentation of Jesus as the one who brought the 'messianic Torah' (Gerhardson 1964:327).

Matthew introduces Jesus as the bearer of the Spirit (Mt 12:18), which attests to his authority in claiming to be the Lord of the Sabbath. His bearing of the Spirit was further demonstrated in his healing activity (Mt 12:9-14). Thus, Matthew also compares Jesus with the Pharisees, whose synagogue ('their synagogue') (Mt 12:10) lacks the Spirit and who were not able to recognise the bearer of the Spirit. Matthew underscores the authority of Jesus in his continuing confrontation with the synagogue ${ }^{6}$.

It is highly significant that Matthew has used pai $\sim$ [child] rather than doul $0 \sim$ [servant]. He changed both the MT and LXX to bring the quotation in conformity with the voice from heaven at two other occasions. Matthew links this

6.The citation also functions as an apology for the Matthean community in its ongoing confrontation with the synagogue. quotation to the highly Christological quotation 'This is my Son, whom I love; with him I am well pleased' that occurs at Jesus' baptism (Mt 3:17) and transfiguration (Mt 17:5). By assimilating this quotation to these two key Christological references, Matthew poses the Christological importance of this servant quotation on the same level as the other two. Matthew moves the focus from a 'servant of God Christology' to a 'Son of God Christology' (Luz 2001:193). By linking these quotations, Matthew implicitly claims that the Messiah's mission as inaugurated with his baptism, is now being fulfilled in the Son of God (France 1998:206). Whilst the Pharisees condemned Jesus and his disciples and plotted how they could kill him (Mt 12:2, 10, 14), God loves him and takes delight in him (Mt 12:18). 'God's verdict about Jesus, then, serves as an important apologetic response to the hostility of the Pharisees' (Neyrey 1982:460). Whilst the Pharisees are deeply displeased with Jesus, God is well pleased. This authorisation of Jesus is evidently important where Jesus claims extraordinary authority to pronounce judgments on Sabbath observance. Matthew strengthens Jesus' crucial Christological statements 'one greater than the temple is here' (Mt 12:6) and 'the Son of Man is Lord of the Sabbath' (Mt 12:8).

The quotation also says that 'he will proclaim (apaggel ei) justice (kris in) to the nations' (Mt 12:18) and will lead justice to victory (Mt 12:9). K risi implies an imminent judgment and victory of justice, whilst a pag gevein is associated with the heralding of good news about Jesus. This is an indication of the judgment that awaits the stubborn unbelieving Pharisees against the disciples of Jesus, who accept the gospel about Jesus.

Jesus' humility and gentleness for the poor and the needy is stated: 'He will not quarrel and cry ... a bruised reed he will not break ...' (Mt 12:19-20). This reaffirms the Jesus' declaration in Matthew 11:28-30 (the prologue to the Sabbath stories), which was practically illustrated in the two Sabbath stories (Mt 12:1-14). Once again, this depiction of Jesus stands in sharp contrast with the mercilessness of the Pharisees.

\section{Conclusion}

The debate in Matthew is not if the Sabbath law should be obeyed, but how it should be done. God's intention with the Sabbath law must be recognised to assure true Sabbath observance.

Jesus, the Son of Man did not come to abolish the Sabbath as some (especially the Pharisees and likeminded people) may have suspected, but to fulfil it. The fulfilment motive of the Sabbath pericopes reiterates Matthew 5:17-20. Matthew's plot focuses on Jesus as the messiah, who fulfilled the whole Scriptural revelation in the Old Testament. The law is not only preserved, but Jesus also brought freshness with his approach to the law. The law requires loyalty and love to God and mercy and kindness towards humans. Jesus lived this commandment to love, also in his observance of the Sabbath. His approach stands in strong contrast to the stubbornness 
of the Pharisees, who heartlessly contested Jesus' authority to extend mercy on the Sabbath. They did not accept the challenge of love and thus, failed to understand the law.

As the Son of God, Jesus has the authority to give this fresh interpretation of the Sabbath commandment. Rest is to be found if people positively respond to his invitation to accept wise teaching. It is God's will that the Sabbath be honoured by way of doing good.

\section{References}

Bacchiocchi, S., 1986, 'Sabbatical Typologies of Messianic redemption', Journal for the Study of Judaism 17, 153-176. doi:10.1163/157006386X00338

Banks, R., 1974, Jesus and the law in the synoptic tradition, University Press, Cambridge.

Brown, R.E., 1966, The Gospel according to John (Anchor Bible), Doubleday, New York.

Carson, D.A., 1982, 'Jesus and the Sabbath in the Four Gospels', in D.A. Carson (ed.), From Sabbath to the Lord's Day, pp. 57-97, Zondervan, Grand Rapids.

Carter, W., 2000, 'Matthew and the margins. A socio-political reading', Journal for the study of the New Testament, suppl. ser. 204.

Davies, W.D., 1963, The setting of the Sermon on the Mount, University Press, Cambridge.

Davies, W.D. \& Allison, D.C., 2004, Matthew, a shorter commentary, T \& T Clark, London \& New York.

Deines, R., 2008, 'Not the law but the Messiah: Law and righteousness in the Gospe of Matthew - an ongoing debate', in D.M. Gurtner \& J. Nolland (eds.), Built upon the Rock. Studies in the Gospel of Matthew, pp. 53-84, Eerdmans, Grand Rapids \& Cambridge.

France, R.T., 1971, Jesus and the Old Testament: His application of Old Testament passages to himself and his mission, Tyndale, London.

France, R.T., 1998, Matthew: Evangelist and Teacher, Paternoster, Exeter.

France, R.T., 2008, 'Matthew and Jerusalem', in D.M. Gurtner \& J. Nolland (eds.), Built upon the Rock. Studies in the Gospel of Matthew, pp. 108-127, Eerdmans, Grand Rapids \& Cambridge.

Gerhardson, B., 1964, Memory and Manuscript: Oral tradition and written transmission in Rabbinic Judaism and Early Christianity, Gleerup, Uppsala \& Lund.
Hagner, D.A., 1993, Matthew 1-13, (Word Biblical Commentaries 33a), Word Books, Dallas.

Hill, D., 1978, 'On the use and meaning of Hosea vi 6 in Matthew's Gospel', New Testament Studies 24, 107-119. doi:10.1017/S0028688500003799

Hummel, R., 1963, Die Auseinandersetzung zwischen Kirche und Judentum im Matthäusevangelium [The confrontation between the Church and Judaism in the Gospel of Matthew], Verlag, München.

Ladd, G.E., 1993, A Theology of the New Testament, Eerdmans, Michigan.

Levine, E., 1976, 'The Sabbath controversy according to Matthew', New Testament Studies 22, 480-483. doi:10.1017/S002868850001016X

Luz, U., 2001, Matthew 8-20, Fortris (Hermeneia), Minneapolis.

Lybeak, L., 1997, 'Matthew's use of Hosea 6:6', in C.M. Tuckett (ed.), The Scriptures in the Gospels. Bibliotheca Ephemeridum Theologicarum Lovaniensium CXXXI, pp. 491-500, Peeters, Leuven.

Mclver, R.K., 1995, 'The Sabbath in the Gospel of Matthew: a paradigm for understanding the law in Matthew?', Andrews University seminary studies 2 231-243.

Menken, M.J.J., 2004, Matthew's Bible. The Old Testament text of the Evangelist, University Press, Leuven.

Moo, J.M., 1984, 'Jesus and the authority of the Mosaic law', Journal for the study of the New Testament 20,3-49. doi:10.1177/0142064X8400602001; doi:10.1177/0142064X8400702001

Morris, L., 1992, The Gospel according to Matthew, Eerdmans, Grand Rapids.

Moule, C.F.D., 1967/1968, 'Fulfilment words in the New Testament: Use and Abuse', New Testament Studies 14, 293-320.

Neyrey, J.H., 1982, 'The thematic use of Isaiah 42:1-4 in Matthew 12', Biblica 63, 457-473.

Patte, D., 1987, The Gospel according to Matthew: A structural commentary on Matthew's faith, Fortress Press, Philadelphia.

Rordorf, W., 1968, Sunday, SCM, London.

Snodgrass, K., 1996, 'Matthew and the law', in D.R. Bauer \& M.A. Powell (eds.) Treasures new and old. Contributions to Matthean studies, pp. 99-127, Scholars Press, Atlanta.

Viljoen, F.P., 2006, 'Jesus' teaching on the torah in the Sermon on the Mount', Neotestamentica 40(1), 135-156.

Viljoen, F.P., 2007, 'Fulfilment in Matthew', Verbum et Ecclesia 28(1), 301-324.

Weiss, H., 1990, 'The Sabbath in the Synoptic Gospels', Journal for the study of the New Testament 38, 13-27. doi:10.1177/0142064X9001203802

Yang, Y-E., 1997, 'Jesus and the Sabbath in Matthew's Gospel', Journal for the Study of the New Testament, suppl. ser. 139. 